\title{
Research, assessment and management of the travertine resources from the Banpotoc-Carpinis deposit (South Apuseni Mts., Romania)
}

\section{Discovery and research of travertine}

\subsection{Prospecting activity}

\subsubsection{Geological reconnaissance}

Usually, the start of research activity in order to discover travertine deposits in a certain zone takes the geological conditions into account, i.e. the possibility of their relatively recent formation. Thus, in the early phase of geological prospecting (i.e. geological reconnaissance; other old Romanian terms defining this phase: preliminary prospecting, regional prospecting, general prospecting) one takes the possibility of carbonated waters existing underground into consideration, these waters were to crosscut limestones and the subsurface emergence of these waters as warm mineral springs, rich in calcium carbonate.

\footnotetext{
* Ph.D., Associate Professor, Faculty of Geology and Geophysics, University of Bucharest, Bucharest, Romania; e-mail:mmar54@yahoo.com; sorin.udubasa@gmail.com

** D.Sc., Associate Professor, Managing Director MinPol GmbH, Dreistetten, Austria; e-mail: gtiess@minpol.com
} 
Although a mineral body is outlined in the phase of detailed prospecting, the possibility of travertine deposits existing in Carpinis area was indicated a long time ago. Pascu (Pascu 1936 in Brana 1967) mentioned the domestic exploitation of travertine by the locals and the existence of two quarries in the area. In 1952, the research was resumed and some outcrops were outlined during the geological mapping at the scale 1:25,000 or 1:20,000. This is also the case of the research in other counties, as Bihor (Baile 1 Mai-Oradea), Hunedoara (Calan Bai, Banpotoc-Carpinis, Geoagiu, Rapolt) and Harghita (Borsec, Minereni-Lueta, Tusnad-Bai, Sandominic).

The analysis and interpretation of these outcrops in light of the local geological setting, lead to a selection of those with high grade of confidence in respect to the quantity and quality of the travertine. These zones have been considered zones of favorable prognosis in which the next stage of prospecting was recommended.

\subsubsection{Detailed prospecting}

In this final stage of prospecting activity, also called final prospecting in Romania (Marinescu 2003), there are two research methods usually employed for travertine: geological and geophysical methods.

Only the geological methods have been used in the Banpotoc-Carpinis area. Detailed mapping (scales 1:10,000 and 1:5,000) clarified the geological structure in the zone and allowed to elaborate geological maps at a higher scale as in the previous stage of geological reconnaissance. According to these maps, geological sections have been made and several drilling sites have been chosen.

Starting with 1954, 8 continuous core drilling have been executed in the north-western zone of Carpinis. The core recovery was of $70-80 \%$ in the cross cutting zone of the deposit.

The drill core mapping allowed the geological bodies or some parts of them with no economic perspectives to be eliminated (insufficient resources or inadequate quality). The research has been continued for those ore bodies with favorable perspectives, outlining the approximate extent of the travertine deposits, doing the quantitative assessment (possible or infferred resources or C2 category) and the qualitative one (mineralogical, petrographical and physico-mechanical analyzes have been carried out on samples from outcrops and drill cores), also assessing the valorization possibilities (summarily, in the laboratory phase).

It has been ascertained that the Banpotoc-Carpinis deposit presents favorable prospects and further steps on geological research (geological exploration) have been recommended. 


\subsection{Exploration activity}

\section{A. Preliminary exploration}

During this preliminary stage of exploration (also called the general exploration in Romania) the travertine ore bodies with favorable economic prospects have been further investigated. As a result of a very detailed mapping activity, geological maps at a scale of 1:2,000 and 1:1,000 were elaborated as well as geological cross sections. The drill holes were placed in a rectangular grid, with $60-100 \mathrm{~m}$ sides. The drilling depths ranged between 27 and $61.5 \mathrm{~m}$.

As in the detailed prospecting, the drilling was made with continuous coring and the core recovery during cross cutting the deposit was $70-80 \%$.

Generally, the geological objectives of this research stage for the mineral substances used as ornamental rocks (Marinescu 2003) have been of significance for travertine too. They consisted on the knowledge of:

- the outline, form, dimensions and the position (strike, dip and depth) of the travertine bodies;

- the thickness of the bodies and its variation along strike and dip;

- the chemical, mineralogical and petrographical composition as well as the physico-mechanical properties of the travertine;

- the existence of qualitative classes and of the barren seams or qualitatively inadequate intercalations.

Economic objectives have also been in view, for instance:

- the laboratory measurements on technical samples from drill cores and outcrops in order to determine the qualitative characteristics and the processing opportunities of the travertine;

- assessment of the geological reserves according to the old Romanian classification system (Marinescu 2003) used at the time of last research (category $\mathrm{C}_{1}$ and further on category $\mathrm{C}_{2}$ ); this is required to justify the next stage of the exploration.

At the end of the preliminary exploration it was ascertained that the travertine from the Banpotoc-Carpinis area meets the qualitative and quantitative requirements of an ore deposit and the research must continue with the detailed exploration.

\section{B. Detailed exploration}

During this final stage of exploration (also called advanced or industrial exploration) the travertine deposit was thoroughly investigated and the obtained information was used to design the exploitation works and the processing flowsheet.

Following the highly detailed mapping activity, geological maps and cross sections with the scale of 1:1,000 or 1:500 were elaborated. In the zone of the future quarry a triangular network of drillings was made, with $40 \mathrm{~m}$ distance between the drillings. An experimental quarry was carried out in this zone apart from the increasing number of drill holes with narrow distances between them as in the previous stage of preliminary prospecting. 
The same geological objectives have been targeted as in the preliminary prospecting stage however the knowledge level attained the highest level possible. The economic objectives focused on the assessment of the technological behavior and ore reserves estimation.

The technological behavior of the travertine was determined using semi-industrial (pilot-scale) and industrial level assays. The travertine reserves reached the highest level possible as a result of the exploration stage. Thus, reserves were estimated according to the old Romanian classification system as follows: category B reserves (measured resources in new classification system) inside the future quarry perimeter and category $\mathrm{C}_{1}$ (indicated resources) outside of it.

The experimental quarry established at the end of this stage of exploration activity provided data about the technical-mining and economic (of capitalization) conditions as well as the most adequate exploitation method. Simultaneously, travertine blocks have been extracted and processed in order to settle the technology of travertine tile production, the tile dimensions and recovery degree of the tiles out of the exploitation blocks.

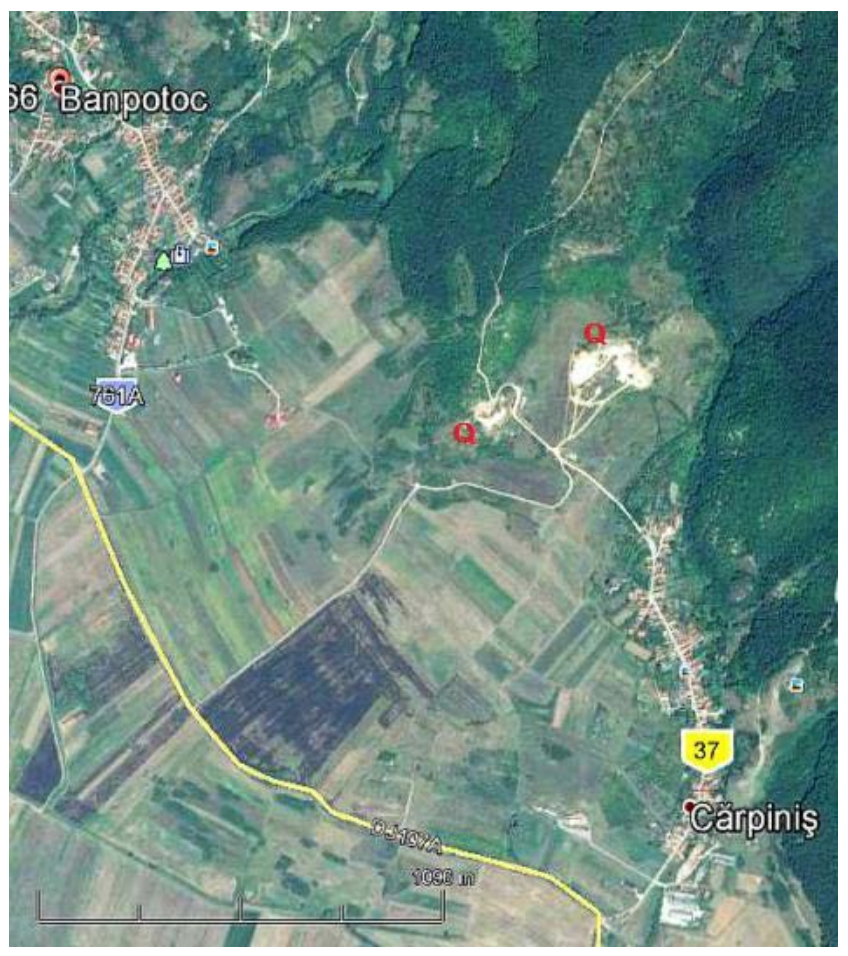

Fig. 1. Satelite image with the location of the Banpotoc-Carpinis travertine deposit. $\mathrm{Q}=$ the location of the travertine quarries. (Image from Google Earth)

Rys. 1. Obraz satelitarny lokalizacji złóż trawertynu w Banpotoc-Carpinis $\mathrm{Q}=$ rozmieszczenie kamieniołomów trawertynu) 


\subsection{Results}

\subsubsection{Deposit location}

The travertine deposit from Banpotoc-Carpinis is located in the south range of the Apuseni Mts., between the two localities with the same names (Fig. 1) in Hunedoara county, at about $4 \mathrm{~km}$ north of the town of Simeria and $1 \mathrm{~km}$ north of the Mures river. The topographic setting is illustrated in Fig. 2.

From the geological point of view, this zone is included in the South Apuseni Mts. Subunit, in which the presence of epimetamorphic crystalline schists is a characteristic feature. These epimetamorphic rocks appear as an island (Rapolt "island") from under the Cretaceous, Neogene and Quaternary sedimentary formations. The travertine deposit is located in the southern border of this "island". Its geological setting is illustrated in Fig. 3.

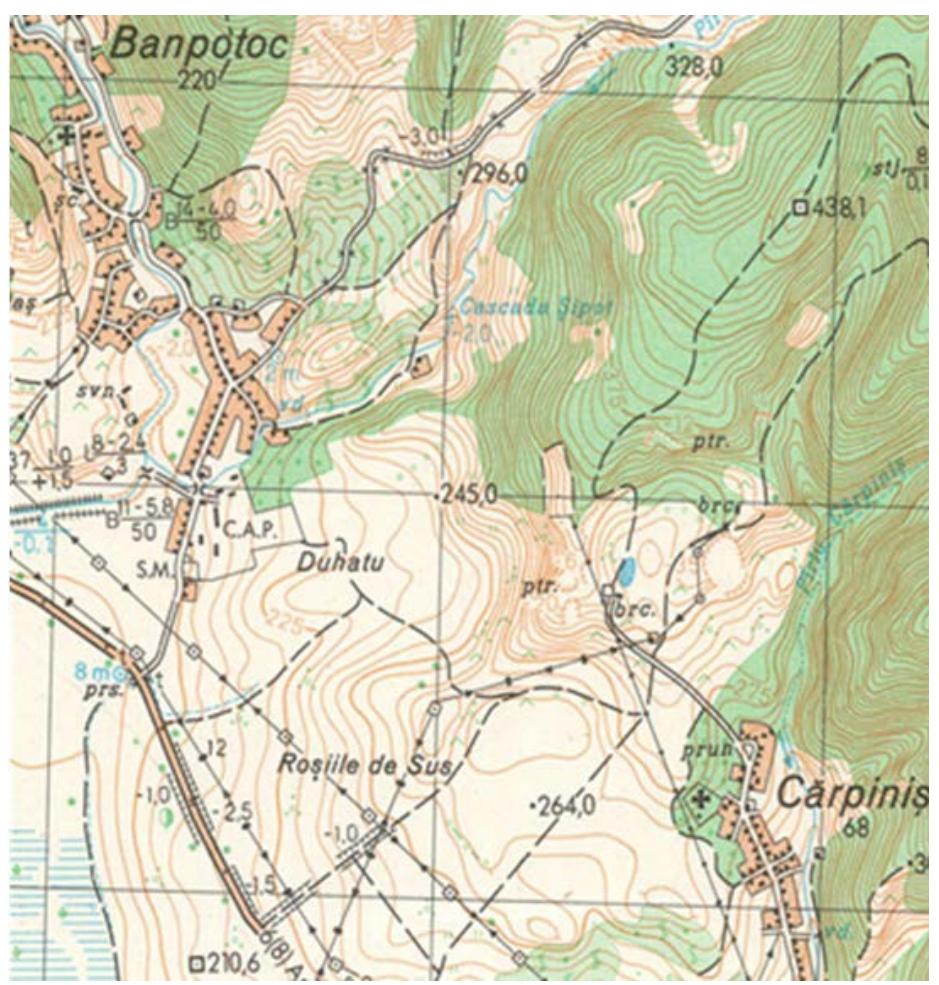

Fig. 2. Topographic map of the Banpotoc-Carpinis deposit and surroundings (after the Topographic Map of Romania)

Rys. 2. Mapa topograficzna złóż trawertynu i otoczenia Banpotoc-Carpinis 


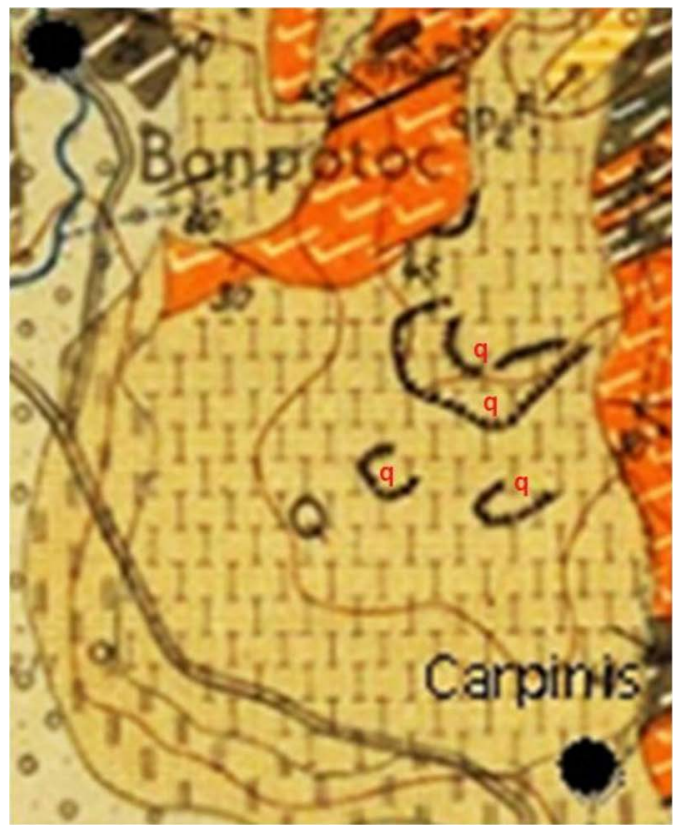

LEGEND

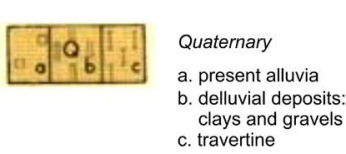

Fig. 3. Geological setting of the Banpotoc-Carpinis deposit (after the Geological Map of Romania, scale 1:50,000, sheet 90 Geoagiu, edited by the Geological Institute of Romania). Other geological formations than Quaternary are epimetamorphic schists

$$
\mathrm{q}=\text { travertine quarries }
$$

Rys. 3. Położenie geologiczne złóż trawertynu w Banpotoc-Carpinis (według mapy geologicznej Rumunii, skala 1: 50 000, arkusz 90 Geoagiu, wydany przez Instytut Geologiczny w Rumunii) Inne formacje geologiczne niż czwartorzędowe to łupki epimetamorficzne $\mathrm{q}=$ kamieniołomy trawertynu

\subsubsection{Deposit genesis}

The deposits have been formed during the Upper Holocene period due to calcium carbonate precipitation from the thermal springs which evolved along several faults. The calcium bicarbonate present in these springs resulted from the slight metamorphosed limestones and dolomites of the epimetamorphic crystalline basement. These carbonaceous rocks have been dissolved by the thermomineral underground waters with high carbonic acid content. When these underground waters emerged at the surface and came in contact with the atmosphere the carbon dioxide was liberated at the same time as the calcium carbonate precipitated. The thickness, degree of compaction and color are variable and explained by the variable flow in time of the springs.

In time, porous calcareous crusts formed around the old springs and on the slopes nearby. These crusts transformed in geological time into travertine due to calcium carbonate precipitation in the pores, vacuoles and fissures through which the thermal bicarbonate water continued to circulate. When the carbon dioxide release was intense due to optimal conditions 
(high temperature, high biotic activity, good aeration) the calcium carbonate precipitation was also massive resulting in limestone intercalations within the travertine (ICPMC 1976).

The present aspects of the travertine (thickness, compaction, color, pore volume) are the results of the influence and interplay of several factors as the springs flow, slope, flow rate and $\mathrm{CaCO}_{3}$ concentration (Panaitescu and Pripoaie 1999).

\subsubsection{Deposit extent}

The Banpotoc-Carpinis deposit is located in the Comoara (Treasure) Hill (or Rachitasu Hill), molding the old relief which is overlain by Neogene argillaceous-sandy formations. It presents outcrops scattered on a surface of about $1 \mathrm{~km}^{2}$ but its total extent is much larger: $800 \mathrm{~m}$ in length, $300 \mathrm{~m}$ in width and approx. $90 \mathrm{~m}$ thickness (ICPMC 1976).

In the lower part it presents a $60 \mathrm{~m}$ layer of compact travertine (slightly vesicular), called Banpotoc travertine. This layer constituted in the past the exploitation target of several quarries. It is overlain by a vesicular travertine layer of a $25-30 \mathrm{~m}$ thickness called Carpinis travertine which is currently exploited. There are $5 \mathrm{~m}$ of altered travertine towards the surface, $3.5-4 \mathrm{~m}$ of clay and $0.5 \mathrm{~m}$ of soil representing the deposit cover.

\section{The resource assessment management}

In each prospecting and exploration stages apart from the geological reconnaissance (when usually the mineral deposit was not discovered or entirely outlined) an evaluation of the quality and quantity of the travertine has been made accounting for the continuation of the research and moving on the next stage respectively. A good travertine quality emphasized by the majority or all of the research works together with the evaluation of a sufficient quantity of ore in order to extract it with profit are essential conditions to continue the research.

The geological conditions of the travertine deposit (also called reservoir conditions at the end of the preliminary prospection and during the detailed exploration) have been also determined in a more and more detailed manner as the research advanced.

An industrial assessment of the deposit was made at the end of the geological research (detailed exploration stage) and before the exploitation stage.

\subsection{Qualitative assessment of the travertine}

Different analyses, observations and measurements were necessary in order to determine the quality of the travertine. Field observations, petrographical, mineralogical and chemical analyses, as well as physico-mechanical, structural measurements and processing tests were carried out on samples from drill cores and mining works in the experimental quarries. 


\section{A. Petrographic and microstructural characteristics}

Carpinis travertine is found in the basement of the deposit, with thicknesses between 0-15 m. It is vesicular, sometimes breccious, friable, with grayish-yellowish and grayish-brownish color, having clay impurities and $\mathrm{SiO}_{2}$ precipitations. The Carpinis travertine gradually passes upwards into massive travertine which is exploitable. The massive travertine has a thickness of 2-40 m, small size vacuoles and whitish-yellowish color.

The top of the sequence includes slab travertine and clay deposits, representing the deposit cover with thicknesses of $1-15 \mathrm{~m}$.

The structure is microcrystalline, amorphous or crustiform, the texture is vesicular or compact to weakly vesicular. There is usually a uniform distribution of the vesicules in the statification plane (Brana et al. 1986).

Several varieties of travertine have been separated under the microscope: allochemical with sparitic, microsparitic and microsparitic with aragonite cement, allochemical with micritic-sparitic, micritic-sparitic with bioclasts and arenitic cement.

The deposit is affected by gravitational fissures which can be open or slightly cemented by calcite or clay. The fissures have an erratic disposal but are at more than $2 \mathrm{~m}$ intervals, influencing in a minor way the size of the exploitation blocks.

\section{B. Mineralogical and chemical characteristics}

From the mineralogical point of view the Carpinis travertine consists of more than $95 \%$ calcite and aragonite. Subordinately, dolomite $(<3 \%)$, limonite and clay minerals $(<3 \%)$, quartz $(<2 \%)$ and accesory minerals are also present.

The oxide chemical composition which reflects the mineralogical composition of the Carpinis travertine, is presented in Table 1 (according to SR EN 1467), in comparison with the composition of travertine from other two deposits in Romania.

\section{Physico-mechanical and processing characteristics}

The average physico-mechanical properties of the travertine from Carpinis deposit, according to SR EN 1467, are presented in Table 2, in comparison with those of travertine from other two deposits in Romania.

Table 1. Oxide percentage composition of the travertine from Carpinis, Geoagiu and Borsec deposits (wt \%)

Tabela 1. Skład procentowy tlenków trawertynu ze złóż Carpinis, Geoagiu i Borsec (\% wag.)

\begin{tabular}{|l|c|c|c|c|c|c|c|c|}
\hline Deposit & $\mathrm{CaCO}_{3}$ & $\mathrm{SiO}_{2}$ & $\mathrm{Al}_{2}$ & $\mathrm{Fe}_{2} \mathrm{O}_{3}$ & $\mathrm{TiO}_{2}$ & $\mathrm{MgO}$ & $\mathrm{Na}_{2} \mathrm{O}$ & $\mathrm{K}_{2} \mathrm{O}$ \\
\hline Geoagiu & $>95$ & $<3$ & 1 & $<0.5$ & $<0.1$ & $<1$ & $<0.2$ & $<0.1$ \\
\hline Carpinis & $95-98$ & $0.0-1.4$ & $0.0-0.7$ & $0.0-0.5$ & $0.0-0.5$ & $0.1-2.9$ & $0.0-0.8$ & $0.0-0.1$ \\
\hline Borsec & 95.8 & 1.4 & 0.5 & 0.2 & 0.0 & 1.6 & 0.1 & 0.0 \\
\hline
\end{tabular}


Table 2. Physical-mechanical properties of the travertine from Carpinis, Geoagiu and Borsec deposits

Tabela 2. Właściwości fizyczno-mechaniczne trawertynu ze złóż Carpinis, Geoagiu i Borsec

\begin{tabular}{|l|c|c|c|c|}
\hline \multicolumn{1}{|c|}{ Parameter } & Units & $\begin{array}{c}\text { Geoagiu } \\
\text { deposit }\end{array}$ & $\begin{array}{c}\text { Carpinis } \\
\text { deposit }\end{array}$ & $\begin{array}{c}\text { Borsec } \\
\text { deposit }\end{array}$ \\
\hline Density & $\mathrm{g} / \mathrm{cm}^{3}$ & 2.70 & 2.70 & 2.68 \\
\hline Apparent density & $\mathrm{g} / \mathrm{cm}^{3}$ & $2.15-2.49$ & $2.30-2.45$ & $2.10-2.40$ \\
\hline Compaction & $\%$ & 89.3 & 88.0 & 91.2 \\
\hline Porosity & $\%$ & 10.7 & 12.0 & $\max 8.8$ \\
\hline Water absorption at normal pressure and temperature & $\%$ & 1.80 & 1.60 & 2.67 \\
\hline Tensile strenght at compression in dry state & $\mathrm{MPa}$ & 0.510 & 0.375 & $0.400-0.700$ \\
\hline Compressive strength after 25 freezing cycles & $\mathrm{MPa}$ & 0.330 & 0.410 & 0.350 \\
\hline Wearing resistance by friction (Böhme) at $440 \mathrm{rot} / \mathrm{min} *$ & $\mathrm{~g} / \mathrm{cm}^{2}$ & 0.70 & 0.22 & 0.35 \\
\hline Strength under mechanical shock* & $\mathrm{MPa}$ & 0.0066 & 0.011 & 0.018 \\
\hline
\end{tabular}

* Parameters acc. to SR EN 1467.

The travertine blocks exploited from the quarries of the Carpinis deposit are lacking fissures, are homogeneous as regards the physico-mechanical properties and can be mecanically cut.

\subsection{Quantitative assessment of the travertine resources and reserves}

The quantitative assessment of the travertine as for any other building stones or ornamental rocks (Preda et al. 2004) has been carried out as existing reserves and resources volume in the ore body, deposit or research perimeter (as a sector of the deposit) using the formula:

$$
\mathrm{R}=\mathrm{S} \cdot \mathrm{G}\left[\mathrm{m}^{3}\right]
$$

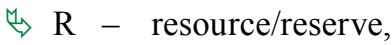

$\mathrm{S}-$ area $\left[\mathrm{m}^{2}\right]$,

$\mathrm{G}-$ thickness [m].

The method of the quantitative assessment of the resources and reserves must be chosen according to the specific features of the deposit or the ore body (Preda et al. 2004). In our case this was done according to the morphology and the thickness of the deposits, 
the presence of the alteration and fissuration zones, compaction degree, presence of the vesicules and caverns (sometimes filled with residual clay), the exploitation method which will be adopted or is used in the adjoining perimeter, the applied research method (bore-hole method) - including the display of the drillholes, core recovery, travertine block recovery during exploitation.

The chosen assessment method was the one of vertical parallel sections using the following formulas:

$$
\begin{gathered}
\mathrm{R}=\mathrm{D} \cdot\left(\mathrm{S}_{1}+\mathrm{S}_{2}\right) \\
\mathrm{R}=\mathrm{D} \cdot\left(\mathrm{S}_{1}+\mathrm{S}_{2}+\sqrt{\mathrm{S}_{1} \cdot \mathrm{S}_{2}}\right) \\
\mathrm{R}=\mathrm{D} \cdot(\mathrm{S} / 3) \\
\mathrm{R}=\mathrm{D} \cdot \mathrm{S}
\end{gathered}
$$

$\Leftrightarrow \mathrm{R} \quad-$ resource (reserve) of travertine $\left[\mathrm{m}^{3}\right]$,

D - the distance between the sections $[\mathrm{m}]$,

$\mathrm{S}_{1}, \mathrm{~S}_{2}-$ the surface of the sections which delimitate the block $\left[\mathrm{m}^{2}\right]$,

$\mathrm{S} \quad-$ the surface of the individual section $\left[\mathrm{m}^{2}\right]$.

Formula (1) was used for the blocks limited by surfaces that differ from one another by less than $40 \%$; formula (2) was used when these surfaces differ with more than $40 \%$; formula (3) for the blocks with a triangular pyramid (tetrahedron) shape; formula (4) for parallelepipedic blocks limited by a single surface.

The obtained values of reserves substantially diminished according to the amount of the vesicles and caverns, of sterile seams and the altered travertine zones.

The present sufficiency of resources of the quarry exploiting a sector of the Carpinis deposit is in the order of tens of years. It can be increased at any time by extending the detailed exploration area.

\subsection{Industrial assessment of the reserves}

The Banpotoc-Carpinis deposit is affected by an irregular fissure system. Where the fissures are closely spaced only smal size travertine blocks can be extracted $\left(\max 0.5 \mathrm{~m}^{3}\right.$ ). Such zones are considered economically inadequate (barren). The fissures are usually spaced at about $2 \mathrm{~m}$ and divide the travertine into $3-4 \mathrm{~m}^{3}$ blocks which are economically exploitable.

The most recent feasibility study (Panaitescu and Pripoaie 1999) evidenced a transformation coefficient from resources (code 331) into reserves (code 111) of 0.50. The average 
coefficient of industrial blocks recovery was calculated at about $50 \%$, thus the industrial reserve is half of the geological reserve. The stripping coefficient is of $0.56 \mathrm{~m}^{3} / \mathrm{m}^{3}$.

\section{Management of the deposit}

\subsection{Management of the travertine exploitation}

The shallow depth of the deposit, covered by a thin layer of soil, clay or weathering zone, the horizontal development of the strata, almost flat area, easy access to the deposit and good possibilities to store the waste material, recommended the surface exploitation, in a quarry.

With passing time (the mining began in 1870), the travertine was exploited in nine distinct quarries, all of small size, located on the same hill, but now only one is still working (Codrea et al. 2005).

All the 3 stages of the exploitation of a mineral deposit are found: opening, preparation for extraction and extraction.

\subsubsection{Opening works}

At the beginning of the Carpinis quarry opening an access road was built which accessed the quarry at $+297 \mathrm{~m}$ level. Maintenance and repair works for this road have been done periodically during the activity of the quarry.

\subsubsection{Preparation works}

The preparation works for the Banpotoc-Carpinis deposit in view of its exploitation consisted of barren rocks removal (soil, clay, altered travertine) which represent the deposit cover. The thickness of the cover has an average value of $5 \mathrm{~m}$.

The clay is removed using the excavator or the bulldozer. The drill-blast method was used for the altered travertine, however, if the deposit is to be preserved (against fissures caused by blasts) a cutting machine can be used (Perrier or CTB).

The elements of the front of the workings are:

- front length: $25-50 \mathrm{~m}$,

- step height: $3 \mathrm{~m}$,

- slope angle: $45-65^{\circ}$.

When the drill-blast method is used the drill holes filled up with explosive are displayed on alignments spaced at $1.5 \mathrm{~m}$. The distance between the two holes is $0.75 \mathrm{~m}$.

The preparation activities are generally specific to the applied exploitation method. At the (actual) Carpinis Quarry, the preparation phase consists in lying out of a flat surface on 
the top of the deposit (following the cover removal), in order to install the cutting machine trail (Marinescu et al. 2005).

The resulted waste material is transported outside the quarry, in the SW part of the mining perimeter. A part of the altered travertine removed from the cover is used for the construction industry.

\subsubsection{Extraction works}

The deposit inside the Carpinis quarry consists of travertine banks slightly inclined, with thicknesses of 1.5-2.0 m. Clay interbeds with low resistance along which the blocks can be easily detached are located between the travertine banks. This situation and the deposit fracturing imposed the use of the downward sloping slices method.

For travertine extraction (the downward sloping slices method, longitudinal cut out with cutting machine variant), the slice is divided into longitudinal strips with Perrier and CTB cutting machines, with $2 \mathrm{~m}$ long arms. The strips have a length of 20-25 m, width of $1.1 \mathrm{~m}$ and a height of $1.5 \mathrm{~m}$ and are detached from subjacent layer along clay separation beds or by mine holes perforation.

Block separation $\left(2.8 \times 1,1 \times 1,5 \mathrm{~m}=4,62 \mathrm{~m}^{3}\right)$ from the strip is made by natural fissure planes or by perforation and detachment with cleats. The travertine recovery as industrial blocks is around $48-50 \%$ (Marinescu et al. 2005).

The works are executed by a 24 persons team (work formation), utilizing the following: S 1500 bulldozer, CD hydraulic excavator, S 1810 tractor, Stalowa Wola type loader, EC 10 electro-compressor, arm cutting machines, P 58 borers, compressed air system (Panaitescu and Pripoaie 1999).
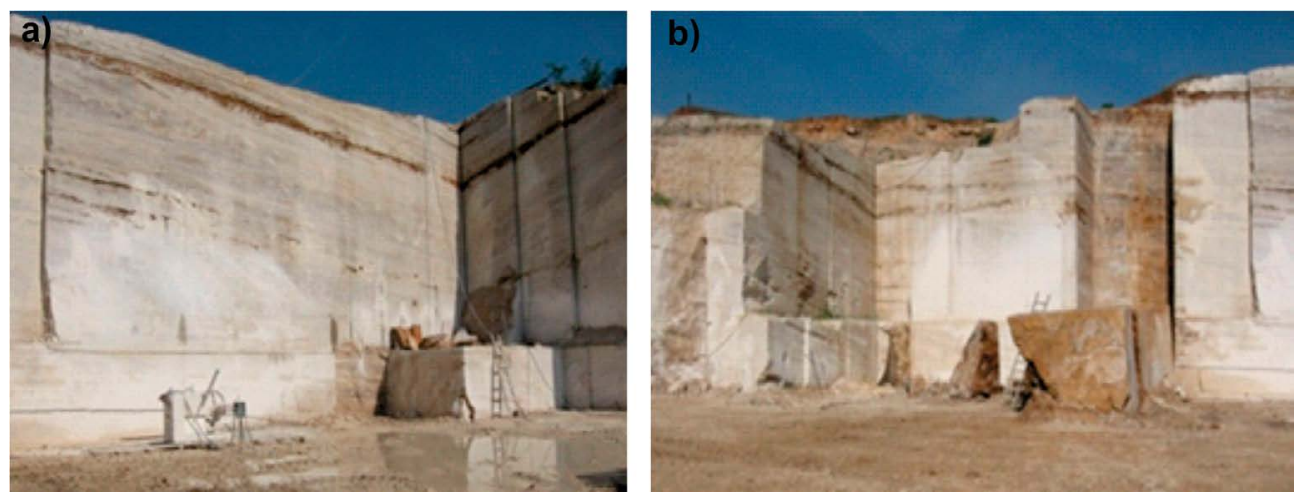

Fig. 4. Images from the Carpinis travertine quarry a) detachment of the final block of a strip; b) industrial blocks of travertine Source: www.StoneContact.com

Rys. 4. Obrazy kamieniołomu trawertynu w Carpinis a) odspojenie ostatniego bloku z pasa trawertynu; b) bloki przemysłowe trawertynu 
The industrial blocks are transported from the Banpotoc-Carpinis deposit by trucks to the beneficiaries or to the processing/treating unit in Simeria. The large size waste material $(100-500 \mathrm{~kg} / \mathrm{block}$ ) is stored at the quarry periphery (from where it is delivered to various beneficiaries which execute damming works and foundations) while the rest is sent to a waste disposal site.

\subsection{Management of the travertine processing}

Good quality travertine is also delivered as blocks, but usually after processing as raw and finite slabs with sizes up to $150 \times 50 \times 2 \mathrm{~cm}$.

The processing of the travertine industrial blocks is made with frames or cutting machines at the processing unit in Simeria. This usually results in rectangular, finite plates and seldom-irregular polygons. On average, 14 to $15 \mathrm{~m}^{2} / \mathrm{m}^{3}$ equivalent of cut and ground plates of a $2 \mathrm{~cm}$ thickness are obtained from one block (Marinescu et al. 2005). Using other type of processing one can provide linear products (steps, kerbs, counters, rods, counter-steps, plinths, frames/borders, window boards ground on one edge, inclined plinths) as well as shaped and sculptured products (lathed balusters, profiled and carved balusters).

The travertine fragments smaller than the industrial blocks and the wastes resulted from blocks cutting are processed into a crusher producing a product called agro-limestone (ground limestone used for improving the soil quality).

\subsection{Travertine use}

The travertine use is determined by its aesthetic aspect and by the possibilities to be easily processed. In time, it was used especially as ornamental rock, for internal and external facing of buildings, except for the horizontal plating/facing and for the plating of high traffic areas or subjected to bad weather (Marinescu et al. 2005). The ornamental material for the inside and outside workings consist of masive platings, profiled or carved products.

The polished platings/covers are close as the ornamental aspect to the carious wood, having brown-grey colors with light-grey or yellowish-brown tones. The fissures as well as some of the pores are very small and partially filled up with aragonite with discrete colors (grayish-white or yellowish) (ICPMC 1976).

The use of travertine platings/covers for the floors and walls improves the aspect and comfort creating better protection against ageing and atmospheric agents, also having easy maintenance. Due to the great similarity with the wood, the travertine can be used in floor coverings similar to a wooden parquet.

Figure 5 displays several aspects and colors of the polished tiles and slabs obtained from Carpinis travertine (www.StoneContact.com). 

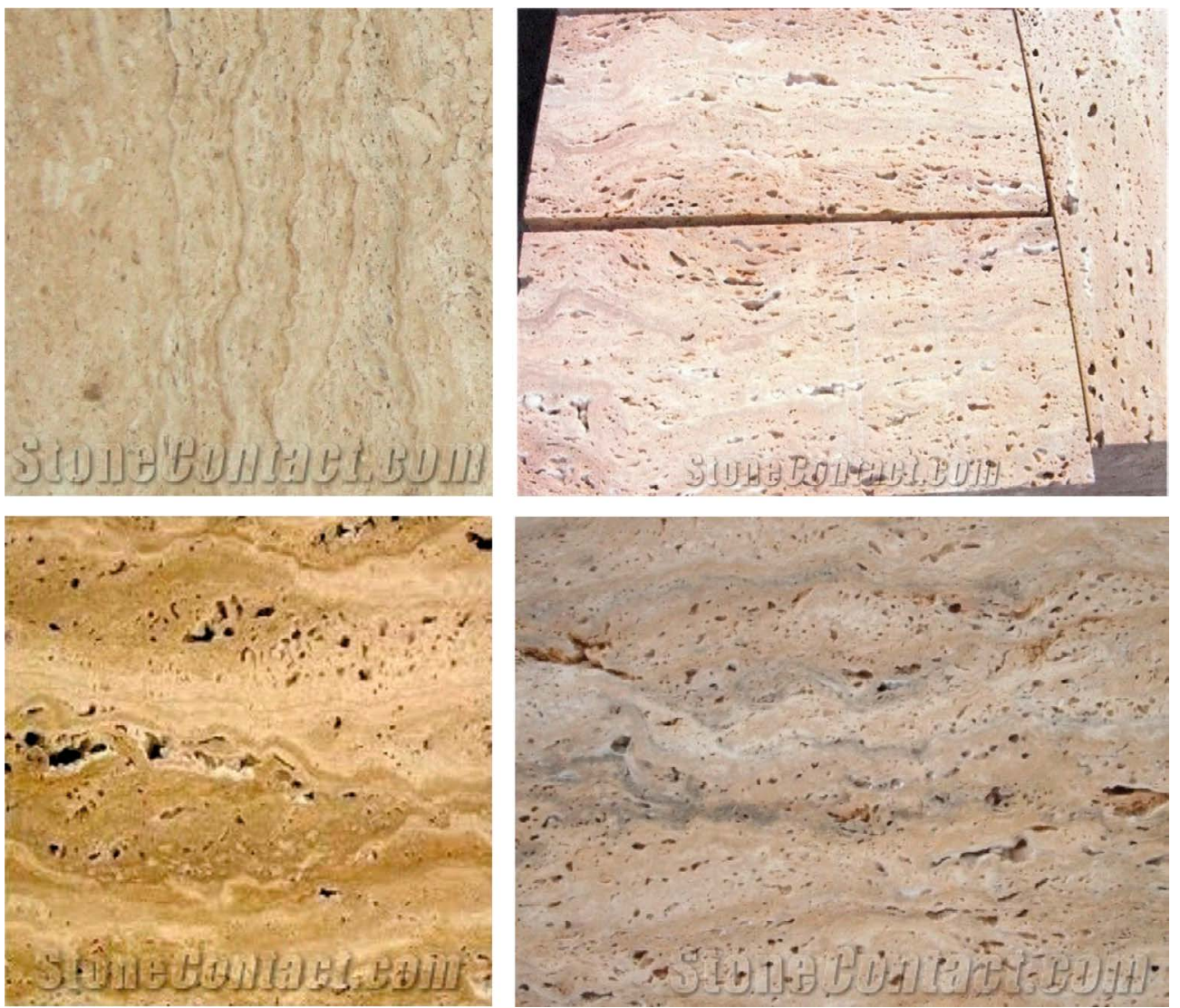

Fig. 5. Carpinis travertine slabs and tiles Source: www.StoneContact.com

Rys. 5. Płyty i płytki trawertynu z Carpinis

Several buildings in Bucharest were completed using the Banpotoc-Carpinis travertine: The Republic Palace, The Telephone Palace (Telekom Building), Mogosoaia Railway Station, Baneasa Bridge, Army Theater (Army House), Athenee Palace Hotel and North Hotel (Brana et al. 1986), National Railway Palace ("CFR" Palace). The famous Romanian artist Constantin Brancusi made several sculptures out of this type of travertine.

The travertine was also used as building stone, borders, paving stones, profiled stones, mosaic slabs, different mosaic types (roman, Venice, granular), material for sculpturing, chemical additive for agriculture (Parvu et al. 1977).

The resulting waste material is used for protection barriers (as rock fills), foundations, building works, or in agriculture (as fertilizer, agro-limestone). The rocks from the cover layer and from the intercalations are used upon the possibilities. For example, the clay was used for the ceramic industry while the alterated travertine became agro-limestone or fodder limestone (Marinescu et al. 2005). 


\section{Conclusions}

Although the Banpotoc-Carpinis deposit contains very large travertine resources, it is presently exploited on a small scale, just in the No. 9 Carpinis Quarry. The research has been done by geological mapping. In the present day quarry perimeter drillings have been made for the reserves assessment using the parallel vertical sections. The resources' sufficiency of the present Carpinis quarry is in the order of tens of years taking the acquired production into account. In the case of necessity, it can be greatly increased by extending the exploration.

For travertine extraction the downward sloping slices method (longitudinal cut out with cutting machine variant) is used, the slice being divided into longitudinal strips with Perrier and CTB cutting machines. The transformation coefficient of the resources (code 331) into reserves (code 111) is 0.50 , the average coefficient of recovery into industrial blocks is of about $50 \%$ and the stripping ratio (coefficient) is $0.56 \mathrm{~m}^{3} / \mathrm{m}^{3}$. An average of 14 to $15 \mathrm{~m}^{2} / \mathrm{m}^{3}$ equivalent of cut and ground plates of a $2 \mathrm{~cm}$ thickness are obtained from one industrial block.

The travertine is used especially as ornamental rock, for the internal and external facing of buildings, except for the horizontal cover/facing and for the high traffic areas or subjected to bad weather. The waste material is capitalized for the protection barrier (as rock fills), foundations, building works, or in agriculture (as fertilizer, agro-limestone). Although in time much larger quantities of travertine have been extracted, today due to the low demand of travertine the annual extraction reaches aprox. $1,000 \mathrm{~m}^{3}$.

\section{REFERENCES}

Brana, V. 1967. Zacaminte nemetalifere din Romania. 472 p. Bucureşti: Editura Tehnică (in Romanian).

Brana et al. 1986 - Brana, V., Avramescu, C. and Călugăru, I. 1986. Substanţe minerale nemetalifere. 367 pp. Bucureşti: Editura Tehnică (in Romanian).

Codrea et al. 2005 - Codrea, V., Barbu, O., Petrescu, I. and Rosu D. 2005. Travertine of Romania: overview on geology and economic significations. Proceedings of 1st International Symposium on Travertine, Denizli. Turkey, pp. 409-414.

ICPMC 1976. Studiul geologic cu calculul rezervelor de travertin de la Carpinis, judetul Hunedoara. Institutul de Cercetare si Proiectare pentru Industria Materialelor de Constructii (ICPMC). ICPMC Archives. Bucureşti (in Romanian)

Marinescu, M. 2003. Management si marketing in geologie. Vol. 1, 196 pp. Editura Universitatii din Bucureşti.

Marinescu et al. 2005 - Marinescu, M., Matei, L., Popa, I. and Gabudeanu, B. 2005. Exploitation and recovery of travertine in Romania. Proceedings of the 1st International Symposium on Travertine, Denizli, Turkey, pp. 415-417.

Panaitescu, M. and Pripoaie, A. 1999. Studiu de fezabilitate privind exploatarea si valorificarea travertinului din perimetrul Carpinis, judetul Hunedoara. SC Belevion SRL. Bucureşti.

Pârvu et al. 1977 - Pârvu, G., Mocanu, Gh., Himbovschi, C. and Grecescu, A. 1977. Roci utile din Romania. 412 pp. Bucureşti: Editura Tehnică (in Romanian). 
Preda et al. 2004 - Preda, Gh., Marinescu, M. and Năstase, G. coord. 2004. Valorificarea resurselor naturale. Vol. 1 : Bazele resurselor naturale. (Valorisation of natural resources. Vol. 1: Basis of natural resources) 404 pp. International University Press. Bucureşti.

SR EN 1467:2012. Natural stone - Rough blocks - Requirements. European Standard.

[Online] Available at: www.StoneContact.com [Accessed: 07.02.2017].

\section{BADANIA, OCENA I ZARZADDZANIE ZASOBAMI TRAWERTYNU ZE ZLÓŻ BANPOTOC-CARPINIS (SOUTH APUSENI MTS., RUMUNIA)}

Słowa kluczowe

zasoby trawertynu, złoża trawertynu, poszukiwanie trawertynu, trawertyn z Carpinis

\section{Streszczenie}

Rumunia nie jest dużym krajem, ale ze względu na bardzo złożoną strukturę geologiczną posiada 110 surowców mineralnych o określonych zasobach. Najwięcej z nich (82) jest eksploatowanych odkrywkowo w ponad 3449 kamieniołomach i odkrywkach. Trawertyn był eksploatowany w Rumunii od czasów starożytnych. Eksploatacja w Brezinta (powiat Mehedinti) jest znana od czasów rzymskich. Chociaż zasoby trawertynu znajdują się w wielu innych rejonach kraju, to tylko dwa złoża trawertynu są obecnie eksploatowane przez Marmosim S.A .: Banpotoc-Carpinis i Geoagiu. Wydobycie trawertynu ze złoża Banpotoc-Carpinis rozpoczęło się w 1870 r. w 9 kamieniołomach, z których obecnie funkcjonuje tylko jeden. W artykule przedstawiono sposób, w jaki przeprowadzono badania i wycenę złoża trawertynu, jego eksploatację i przeróbkę oraz zastosowanie.

\section{RESEARCH, ASSESSMENT AND MANAGEMENT OF THE TRAVERTINE RESOURCES FROM THE BANPOTOC-CARPINIS DEPOSIT (SOUTH APUSENI MTS., ROMANIA)}

\section{Keywords}

travertine resources, travertine deposit, travertine prospecting, travertine exploring, Carpinis travertine

\section{Abstract}

Romania is not a large country but, due to the very complex geological structure, it has 110 mineral and power substances with identified and quantified resources and reserves. In time, the most numerous from these (82) have been exploited at the ground surface, in over 3,492 identified quarries and open pits. Travertine has been exploited since ancient times in Romania The exploitation of Brezinta 
(Mehedinti county) has been known since the Roman times. Although resources are found in many other zones, only two travertine deposits are presently exploited by Marmosim S.A.: Banpotoc-Carpinis and Geoagiu. Travertine extraction began at the Banpotoc-Carpinis deposit in 1870 and 9 quarries have functioned during time from which only one is still active today. This paper presents the way in which the research and valuation of the deposit was made, how the exploitation and processing of the travertine is made nowadays and what are its uses. 
